\title{
Purification and Properties of Three Types of Xylanases Induced by Methyl $\beta$-Xyloside from Streptomyces sp.
}

\author{
Masaki MARUI, Kotoyoshi NAKANISHI* and Tsuneo YASUI \\ Institute of Applied Biochemistry, University of Tsukuba, \\ Sakura-mura, Niihari-gun, Ibaraki 305, Japan
}

Received March 22, 1985

\begin{abstract}
When mycelia of Streptomyces sp. No. 3137 were cultivated in a medium containing methyl $\beta$ xyloside, xylanases (EC 3.2.1.8) were inductively produced into the medium. Three types of enzyme from the culture filtrate have been purified by ultrafiltration with DIAFLO UM-10, chromatography on DEAE-Sephadex A-25, gel filtration on Bio Gel P-100, and isoelectric focusing with Servalyt $6 \sim 8$ or $9 \sim 11$. The three purified enzymes, tentatively named X-I, X-II-A, and X-II-B, were homogeneous by polyacrylamide gel electrophoresis at $\mathrm{pH}$ 4.3. The molecular weight of X-I was about 50,000 by SDS-polyacrylamide gel electrophoresis or gel filtration on Bio Gel P-100. The molecular weight of X-II-A and X-II-B were both approximately 25,000 by SDS-polyacrylamide gel electrophoresis and that of X-II-B was 25,680 by the sedimentation-equilibrium method. X-I had an isoelectric point at 7.10, and X-II-A and X-II-B had different isoelectric points, 10.06 and 10.26 , respectively. The three enzymes were optimally active at $60 \sim 65^{\circ} \mathrm{C}$ and stable to $55^{\circ} \mathrm{C}$. The optimal pH of X-I, X-II-A, and X-II-B were $\mathrm{pH} 5.5 \sim 6.5,5.0 \sim 6.0$, and 5.0 6.0, respectively. The ranges of two X-II's pH stability ( $\mathrm{pH} 1.5 \sim 11.5)$ were wider than that of X-I's (pH 3.0 10.5). These purified preparations hydrolyzed xylotriose, xylotetraose, and xylan but not xylobiose, cellobiose, maltose, carboxymethyl cellulose, or soluble starch. Their actions were inhibited by $\mathrm{Hg}^{2+}$ and $\mathrm{Fe}^{3+}$ ions, sodium dodecyl sulfate, and $\mathrm{N}$-bromosuccinimide.
\end{abstract}

There are many kinds of microorganisms which can produce xylanase (EC 3.2.1.8. $\beta$-1,4xylan xylanohydrolase) in the presence of xylan as a carbon source. ${ }^{1)}$ It has been reported that the enzyme system of Streptomyces ${ }^{2}$ ) except Streptomyces ostreogriseus ${ }^{7)}$ consists of one xylanase. We found that the xylanases of Streptomyces sp. No. 3137 are produced in the presence of an inducer $^{8)}$ and $\beta$-xylosides are effective and non-metabolizable inducers for the xylanase production of this microorganism..$^{9 \sim 11)}$ The properties of xylanases induced by xylan have been investigated, ${ }^{12)}$ however, there has been no report about those xylanases that are produced by certain inducers, not by xylan. It is expected that the xylanase produced by induction is of such high purity that the purification should be more convenient. In this report the purification and properties of xylanases induced by methyl $\beta$ xyloside have been detailed.

\section{MATERIALS AND METHODS}

Microorganisms. Streptomyces sp. No. 3137 isolated from soil ${ }^{8)}$ was used through this experiment. The microorganism was grown on Bennett agar ${ }^{13)}(0.1 \%$ glucose, $0.2 \%$ NZ Amine, $0.1 \%$ yeast extract, $0.1 \%$ beef extract, and $2.0 \%$ agar) and stored until use.

Materials. Xylan was "Sanpearl," a by-product from the mercerization process in pulp manufacturing, supplied by Sanyo Kokusaku Pulp Co., Ltd. Xylooligosaccharides were prepared from a xylan hydrolyzate by Streptomyces xylanase by the method of Kusakabe et al. ${ }^{14,15)}$ Methyl $\beta$ xyloside was synthesized from xylose and methanol using a cationic resin as catalyst by the method of Bollenback. ${ }^{16)}$ DEAE-Sephadex A-25 was a product of Pharmacia Fine Chemicals Inc., Uppsala, Sweden. Bio Gel P-100 was purchased from Bio-Rad Laboratory, California, U.S.A. Servalyt $6 \sim 8$ and $9 \sim 11$ as carrier ampholytes for isoelec-

* Present address: The Institute of Enology and Viticulture, Yamanashi University, Kofu, Yamanashi 400, Japan. Abbreviations: SDS, sodium dodecyl sulfate; EDTA, ethylenediamine tetraacetic acid. 
tric focusing were products of Serva Feinbiochemica $\mathrm{GmbH}$ and Co., F. R. Germany. Corn Steep Liquor (C.S.L.) was a gift from Nippon Shokuhinkako Co., Ltd. bovine serum albumin was a product of Wako Pure Chemical Industries, Ltd. The other chemicals used were of reagent grade and commercially available.

Xylanase production. One liter of the 1 st medium contained $30 \mathrm{~g}$ of glucose, $3 \mathrm{~g}$ of urea, $1 \mathrm{~g}$ of yeast extract, $10 \mathrm{~g}$ of $\mathrm{KH}_{2} \mathrm{PO}_{4}, 0.5 \mathrm{~g}$ of $\mathrm{MgSO}_{4} \cdot 7 \mathrm{H}_{2} \mathrm{O}$, and $5 \mathrm{~g}$ of C.S.L. One loopful of spores from a Bennett agar slope was inoculated into a $500-\mathrm{ml}$ shake flask containing $100 \mathrm{ml}$ of the $1 \mathrm{st}$ medium, and the flask was incubated on a shaker' at 120 strokes per minute at $36^{\circ} \mathrm{C}$ for $40 \mathrm{hr}$. Mycelia obtained from the 1 st culture were put into a $500-\mathrm{ml}$ shake flask with $100 \mathrm{ml}$ of the $2 \mathrm{nd}$ medium containing $0.3 \mathrm{~g}$ of methyl $\beta$-xyloside, $0.2 \mathrm{~g}$ of $\mathrm{KH}_{2} \mathrm{PO}_{4}$, and $0.01 \mathrm{~g}$ of $\mathrm{MgSO}_{4} \cdot 7 \mathrm{H}_{2} \mathrm{O}$. The conditions of incubation were the same as that of the 1 st culture except for the time, $24 \mathrm{hr}$.

Xylanase assay. Xylanase activity was measured by incubating $0.2 \mathrm{ml}$ of diluted enzyme solution with $1.0 \mathrm{ml}$ of $2 \%$ xylan solution and $0.8 \mathrm{ml}$ of McIlvaine buffer ( $\mathrm{pH} \mathrm{5.5)}$ for $10 \mathrm{~min}$ at $55^{\circ} \mathrm{C}$, and measuring the released reducing sugar by the method of Somogyi. ${ }^{17)}$ Xylan used for the determination of enzyme activity was prepared as follows: Xylan was dissolved into $5 \% \mathrm{NaOH}$ and precipitated with addition of an equal volume of ethanol. The precipitate was collected by centrifugation and suspended to water. The suspension was adjusted with acetic acid at pH 5 and washed with ethanol and acetone. After drying, the xylan was powdered by a mortar and pestle. One unit of enzyme activity was defined as the amount causing production of $1 \mu \mathrm{mol}$ of reducing sugar as a xylose equivalent per minute, under optimal conditions of measurement.*1

Protein estimation. Protein was measured by the method of Lowry et al., ${ }^{18)}$ using bovine serum albumin as the standard, or from the absorbance at $280 \mathrm{~nm}$.

Carbohydrate estimation. The carbohydrate content of xylanases was measured by the phenol-sulfuric acid method $^{19)}$ and the orcinol- $\mathrm{Fe}^{3+}$ method. ${ }^{20)}$

Slab polyacrylamide gelelectrophoresis. A polyacrylamide gel was prepared by the method of Reisfeld et al. ${ }^{21)}$ The "pH $4.3 \sim 10 \% "$ gel was set in a slab $(50 \times 75 \times 1 \mathrm{~mm})$. The electrophoresis was done for $45 \mathrm{~min}$ at $15 \mathrm{~mA}$ and room temperature with a KS-8010MSE apparatus, Marysol Co., Ltd., Japan, and the gel was stained with a solution of $0.25 \%$ Coomassie Brilliant Blue R-250-acetic acidmethanol ( $5: 1: 5$ by volume) to locate the protein bands.

Sedimentation analysis. The sedimentation-equilibrium was done with an ultracentrifugal machine (MSE
Centriscan 75II, MSE, England). The centrifugation was $13,000 \mathrm{rpm}$ for $24 \mathrm{hr}$ and the system came to an equilibrium state. By measuring the concentration of the protein at $280 \mathrm{~nm}$ as a function of the distance from the center of rotation, the molecular weight can be calculated.

Isoelectric focusing. The isoelectric focusing procedure followed that of Matsuo and Horio, ${ }^{22)}$ with $110-\mathrm{ml}$ columns (LKB Produkter AB, Bromma, Sweden). Servalyt $6 \sim 8$ or $9 \sim 11$ ampholyte were employed. The focusings were done for $48 \mathrm{hr}$ at $900 \mathrm{~V}$ and $4^{\circ} \mathrm{C}$, and fractions of $2.0 \mathrm{ml}$ were removed from the bottom of the column in the usual manner. ${ }^{22)}$

Hydrolysis of xylooligosaccharides. Ten units of enzyme in $1 \mathrm{ml}$ of McIlvaine buffer ( $\mathrm{pH} 5.5$ ) containing $1 \%$ xylooligosaccharides was incubated at $35^{\circ} \mathrm{C}$, and aliquots of the incubation mixtures were withdrawn at $0,1,3,6$, and $12 \mathrm{hr}$ and were kept in a boiling water bath for $1 \mathrm{~min}$ to stop the enzyme reactions. The sugars were identified by thin layer chromatography. Samples of hydrolyzates were spotted on cellulose plates (TLC plastic sheets cellulose F254, Merck) and developed by the ascending technique in a solvent system, $n$-butanol-pyridine-water $(6: 4: 3$ by volume) at room temperature. Sugars were detected with silver nitrate-sodium hydroxide reagent. ${ }^{23)}$

\section{RESULTS}

\section{Xylanase purification}

All operations were done below $5^{\circ} \mathrm{C}$. The purification was summarized in Table I.

Step 1. Ultrafiltration with DIAFLO UM-10. The second culture filtrate $(2500 \mathrm{ml})$ was concentrated to one-tenth of the original volume $(250 \mathrm{ml})$ by ultrafiltration with DIAFLO UM10.

Step 2. Chromatography on DEAESephadex $A-25$. The concentrated filtrate $(250 \mathrm{ml})$ was put on a DEAE-Sephadex A-25 column $(2 \times 60 \mathrm{~cm})$ previously buffered with McIlvaine buffer (pH 5.5). The effluent $(300 \mathrm{ml})$ was decolorized by this column and then was concentrated to $30 \mathrm{ml}$ by an evaporator under reduced pressure at $35^{\circ} \mathrm{C}$.

Step 3. Gel filtration on Bio Gel P-100. The concentrated effluent $(10 \mathrm{ml})$ was put on a Bio Gel P-100 column $(2 \times 90 \mathrm{~cm})$ previously buffered with McIlvaine buffer ( $\mathrm{pH}$ 5.5). Filtration was done with the same buffer at $4^{\circ} \mathrm{C}$ at

\footnotetext{
*1 One unit by this assay method corresponds to 1.5 units by the method described in our previous paper. ${ }^{8)}$
} 
Table I. Purification of Xylanases from Streptomyces sp. No. 3137

\begin{tabular}{|c|c|c|c|c|c|}
\hline Step & $\begin{array}{l}\text { Volume } \\
\text { (ml) }\end{array}$ & $\begin{array}{l}\text { Protein } \\
(\mathrm{mg})\end{array}$ & $\begin{array}{l}\text { Activity } \\
\text { (units) } \\
\times 10^{3}\end{array}$ & $\begin{array}{c}\text { Specific } \\
\text { activity } \\
\text { (units/mg) }\end{array}$ & $\begin{array}{c}\text { Yield } \\
(\%)\end{array}$ \\
\hline Culture filtrate & 2500 & 4900 & 200 & 41 & 100 \\
\hline UM-10 & 250 & 2700 & 180 & 67 & 90 \\
\hline DEAE-Sephadex A-25 & 300 & 2100 & 168 & 80 & 84 \\
\hline \multicolumn{6}{|l|}{ Bio Gel P-100 } \\
\hline X-I & 150 & 340 & 46 & 135 & 23 \\
\hline $\begin{array}{l}\text { X-II } \\
\text { (sum) }\end{array}$ & 130 & 460 & 66 & 143 & $\begin{array}{c}33 \\
(56)\end{array}$ \\
\hline \multicolumn{6}{|l|}{ Isoelectric focusing } \\
\hline X-I & & 260 & 42 & 161 & 21 \\
\hline X-II-A & & 132 & 14 & 106 & 7 \\
\hline $\begin{array}{l}\text { X-II-B } \\
\text { (sum) }\end{array}$ & & 290 & 45 & 155 & $\begin{array}{c}23 \\
(51)\end{array}$ \\
\hline
\end{tabular}

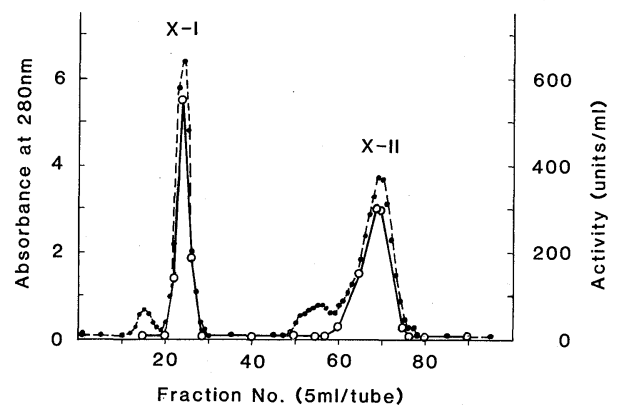

Fig. 1. Bio Gel P-100 Column Chromatography.

The concentrated effluent from DEAE-Sephadex A-25 column chromatography $(10 \mathrm{ml})$ was put on a Bio Gel P100 column $(2 \times 90 \mathrm{~cm})$ equilibrated with ten times diluted McIlvaine buffer (pH 5.5). The flow rate was $10 \mathrm{ml} / \mathrm{hr}$ and fractions of $5 \mathrm{ml}$ were collected. Symbols: $\mathrm{O}-\mathrm{O}$, xylanase activity; --- absorbance at $280 \mathrm{~nm}$.

the rate of $7 \mathrm{ml} / \mathrm{hr}$. Xylanase activities were recovered in two fractions, tubes $20 \sim 29$ and $59 \sim 84$ ( $5 \mathrm{ml}$ per tube), which were named X-I and X-II, respectively (Fig. 1). The two fractions were separately dialyzed against distilled water and concentrated to $1 \mathrm{mg}$ of protein $/ \mathrm{ml}$ by an evaporater under reduced pressure at $35^{\circ} \mathrm{C}$.

Step 4. Isoelectric focusing with Servalyt $6 \sim 8$ or $9 \sim 11$. The concentrated X-I or X-II $(10 \mathrm{ml})$ was put on a column of $110-\mathrm{ml}$ capacity for isoelectric focusing. The pattern of X-I using Servalyt $6 \sim 8$ is shown in Fig. 2. Xylanase activity was recovered in one fraction, which

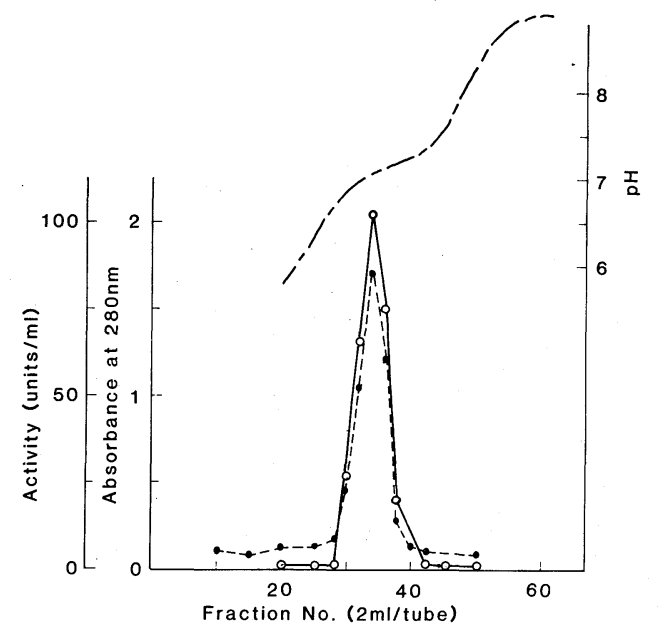

FIG. 2. Isoelectric Focusing of X-I with Servalyt $6 \sim 8$.

The dialyzed and concentrated X-I fraction (about $10 \mathrm{ml}$ ) was put on a $110-\mathrm{ml}$ column containing $1 \%$ carrier ampholyte $\mathrm{pH} 6 \sim 8$ (Servalyt $6 \sim 8$ ). The voltage was adjusted to $900 \mathrm{~V}$. After this was focused for $48 \mathrm{hr}$ at $4^{\circ} \mathrm{C}$, fractions of $2 \mathrm{ml}$ were collected. Symbols: $\bigcirc-\bigcirc$, xylanase activity; --- absorbance at $280 \mathrm{~nm} ;--\ldots, \mathrm{pH}$.

was named X-I, and the only peak of protein was in the same fraction. The isoelectric point of X-I was 7.10. The pattern of X-II using Servalyt $9 \sim 11$ showed two fractions of $x y-$ lanase activity (Fig. 3). Their isoelectric points were 10.06 and 10.26 , which were named X-IIA and X-II-B, respectively. The activity of XII-B was three times as great as that of X-II$A$, and the specific activity of X-II-B was one 


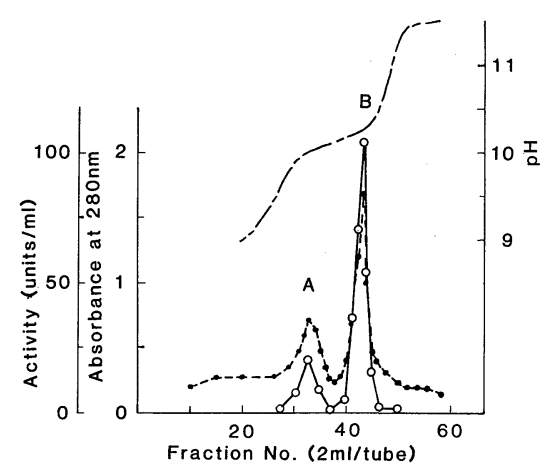

FIG. 3. Isoelectric Focusing of X-II with Servalyt $9 \sim 11$.

The dialyzed and concentrated X-II fraction (about $10 \mathrm{mg}$ ) was put on a $110-\mathrm{ml}$ column containing $1 \%$ carrier ampholyte pH 9 11 (Servalyt 9 11). The voltage was adjusted to $900 \mathrm{~V}$. After this was focused for $48 \mathrm{hr}$ at $4^{\circ} \mathrm{C}$, fractions of $2 \mathrm{ml}$ were collected. Symbols: $\bigcirc-\bigcirc$, xylanase activity; --- absorbance at $280 \mathrm{~nm} ;---, \mathrm{pH}$.

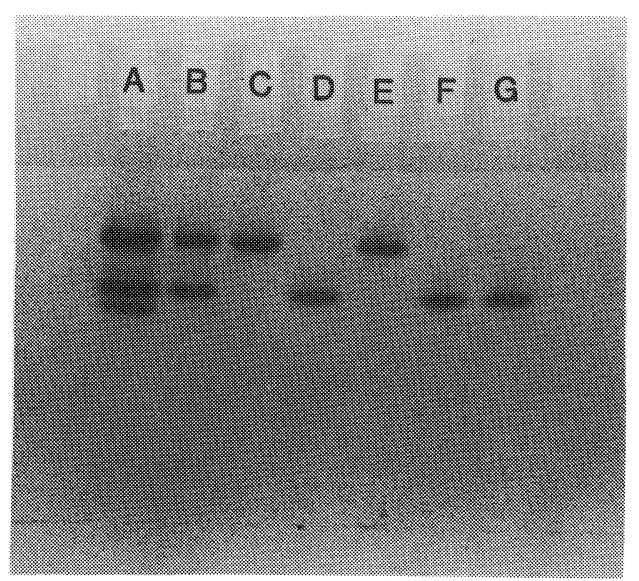

FIG. 4. Slab Electrophoretic Pattern of Xylanase Preparation in Each Purification Step.

Proteins $(5 \sim 10 \mu \mathrm{g})$ were put on a slab $(50 \times 75 \times 1 \mathrm{~mm})$ of $10 \%$ polyacrylamide gel and allowed to migrate in $\beta$ alanine-acetic acid buffer ( $\mathrm{pH} \mathrm{4.3)}$ at $15 \mathrm{~mA}$ for $45 \mathrm{~min}$. Proteins were stained with a solution of $0.25 \%$ Coomassie Brilliant Blue R-250-acetic acid-methanol ( $5: 1: 5$ by volume). Symbols: A, Culture filtrate; B, Effluent of DEAESephadex A-25 chromatography; C, X-I fraction of Bio Gel P-100 gel filtration; D, X-II fraction of Bio Gel P-100 gel filtration; E, X-I fraction of isoelectric focusing with Servalyt $6 \sim 8$; F, X-II-A fraction of isoelectric focusing with Servalyt 9 11; G, X-II-B fraction of isoelectric focusing with Servalyt $9 \sim 11$.

and a half times that of X-II-A. The contaminating carrier ampholytes in the three fractions were removed by salting out with am-

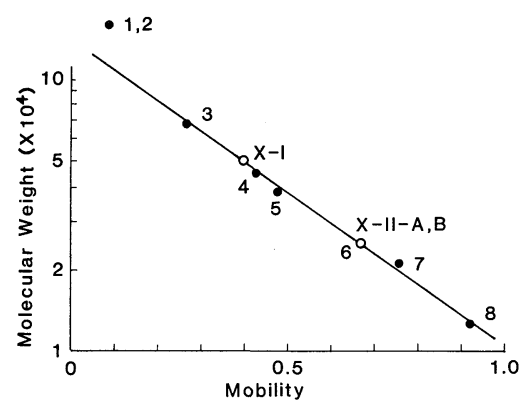

FIG. 5. Measurement of Molecular Weight of Xylanases.

Samples containing $0.01 \mathrm{~m}$ phosphate buffer $(\mathrm{pH} 7.2), 1 \%$ SDS, 5\% 2-mercaptoethanol, 25\% glycerol, and $0.1 \%$ protein were left for $5 \mathrm{~min}$ in boiling water. Then samples of $5 \sim 10 \mu \mathrm{l}$ were put on a slab $(50 \times 75 \times 1 \mathrm{~mm})$ of $10 \%$ polyacrylamide gel and allowed to migrate in $0.1 \mathrm{M}$ phosphate buffer ( $\mathrm{pH} 7.2$ ) containing $0.1 \% \mathrm{SDS}$ at $15 \mathrm{~mA}$ for $7 \mathrm{hr}$. Proteins were stained with a solution of $0.25 \%$ Coomassie Brilliant Blue R-250-acetic acid-methanol ( $5: 1: 5$ by volume). Symbols and molecular weights of standard proteins: 1, RNA polymerase from $E$. coli $\beta^{\prime}-$ subunit (mol wt, 165,000); 2, RNA polymerase from $E$. coli $\beta$-subunit $(155,000) ; 3$, bovine serum albumin $(68,000)$; 4 , ovalbumin $(45,000) ; 5$, RNA polymerase from $E$. coli $\alpha$ subunit $(39,000) ; 6$, chymotrypsinogen $A(25,000) ; 7$, trypsin inhibitor $(21,500) ; 8$, cytochrome $c(12,500)$.

monium sulfate $(70 \%$ saturation). After that the enzyme solutions were dialyzed against distilled water with cellulose tubes. Slab poly acrylamide gel electrophoresis of the purified xylanases gave a single protein band in the gel system "pH 4.3 10\%" (Fig. 4).

\section{Molecular weight}

The molecular weights of X-I, X-II-A, and $\mathrm{X}$-II-B were found by SDS-polyacrylamide gel electrophoresis (Fig. 5). They were estimated to be approximately $50,000,25,000$ and 25,000 , respectively. The molecular weight of X-I estimated by gel filtration on Bio Gel P100 column was also approximately 50,000 . The molecular weight determination of X-II-A and X-II-B by gel filtration failed because of interaction between the enzymes and the gel. The molecular weight of X-II-B calculated from the sedimentation analysis was 25,680 .

\section{Carbohydrate content}

The carbohydrate contents in X-I, X-II-A 


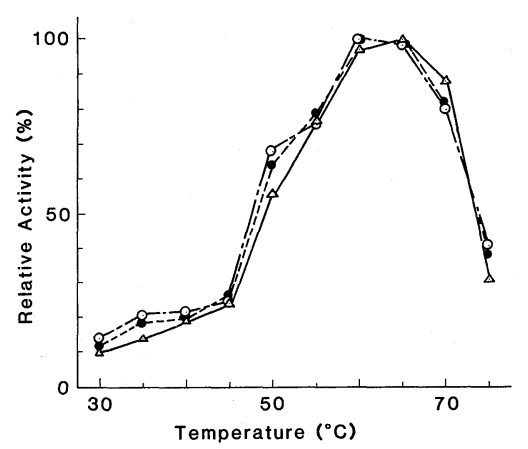

FIG. 6. Effects of Temperature on Xylanase Activities.

The reaction mixtures containing $1.0 \mathrm{ml}$ of $2 \%$ xylan, $0.8 \mathrm{ml}$ of McIlvaine buffer ( $\mathrm{pH} \mathrm{5.5)}$, and $0.2 \mathrm{ml}$ of enzyme solution (10 units) were incubated at various temperatures for $10 \mathrm{~min}$. Symbols: $\triangle-\triangle, \mathrm{X}-\mathrm{I}$; $-\mathrm{--O}, \mathrm{X}-\mathrm{II}-\mathrm{A}$; $\mathrm{O}-\cdot-\mathrm{O}, \mathrm{X}-\mathrm{II}-\mathrm{B}$.

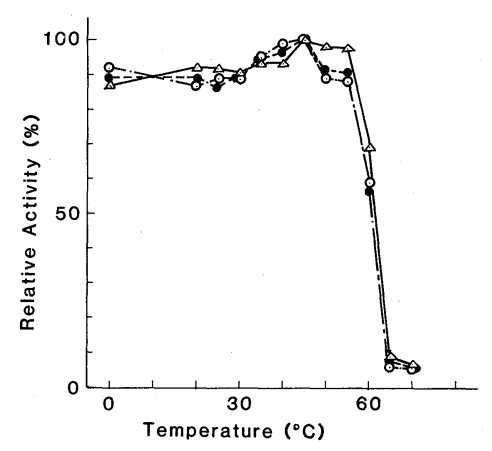

FIG. 7. Thermal Stabilities of Xylanases.

Enzyme solutions (100 units/ml), pH 5.5, were incubated for $30 \mathrm{~min}$ at various temperatures and then the remaining activities were measured by the standard assay method. Symbols: $\triangle-\triangle$, X-I; ---O, X-II-A; O---O, X-II-B.

and X-II-B were less than $1 \%$ (carbohydrate/protein, w/w) as glucose by the phenol-sulfuric acid method ${ }^{19)}$ and under $0.5 \%(\mathrm{w} / \mathrm{w})$ as xylose by the orcinol- $-\mathrm{Fe}^{3+}$ method. ${ }^{20)}$

\section{Effects of Temperature}

The activity of the enzymes was measured at various temperatures from 30 to $75^{\circ} \mathrm{C}$ for $10 \mathrm{~min}$ at $\mathrm{pH}$ 5.5. The optimal temperatures of $\mathrm{X}-\mathrm{I}, \mathrm{X}-\mathrm{II}-\mathrm{A}$, and X-II-B were $60 \sim 65^{\circ} \mathrm{C}$ (Fig. 6). The enzymes were incubated at various

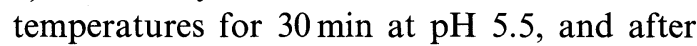
that the remaining activities were measured. The enzymes were stable up to $55^{\circ} \mathrm{C}$ (Fig. 7).

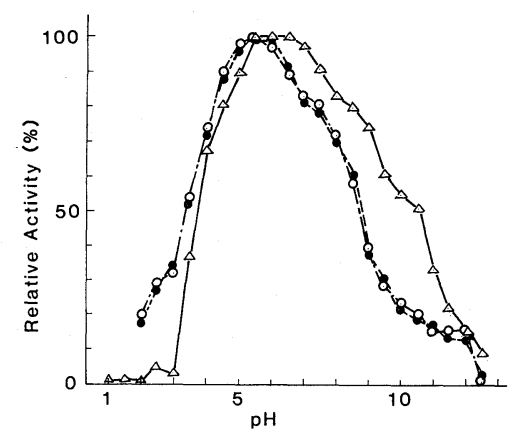

FIG. 8. Effects of $\mathrm{pH}$ on Xylanase Activities.

The reaction mixtures containing $1.0 \mathrm{ml}$ of $2 \%$ xylan solution (10 units) were incubated for $10 \mathrm{~min}$ at $55^{\circ} \mathrm{C}$. The buffers used were $0.1 \mathrm{M}$ hydrochloric acid-sodium acetate buffer ( $\mathrm{pH} 1.0 \sim 4.5$ ), $0.1 \mathrm{M}$ acetate buffer ( $\mathrm{pH} 4.0 \sim 6.5$ ), McIlvaine buffer ( $\mathrm{pH} 4.0 \sim 8.0$ ), $0.1 \mathrm{M}$ phosphate buffer (pH 6.0 8.5), $0.1 \mathrm{M}$ ammonium hydroxide-ammonium chloride buffer ( $\mathrm{pH} 7.5 \sim 10.0$ ) and $0.1 \mathrm{M}$ glycine buffer (pH 9.5 12.5). Symbols: $\triangle-\triangle, \mathrm{X}-\mathrm{I}$; $\bigcirc--\mathrm{O}, \mathrm{X}-\mathrm{II}-\mathrm{A}$; O-- -O, X-II-B.

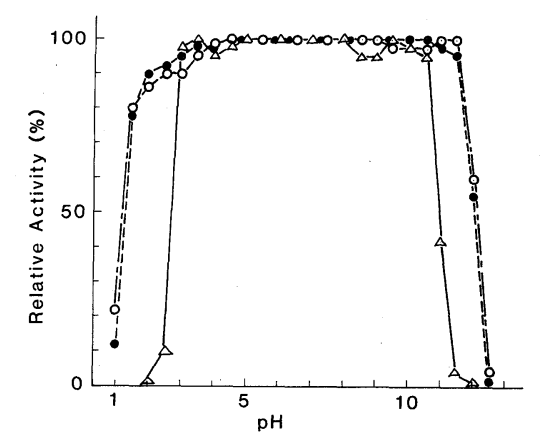

FIG. 9. pH-Stabilities of Xylanases.

Enzyme solutions (100 units $/ \mathrm{ml}$ ) of various $\mathrm{pH}$ values were

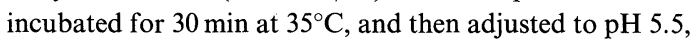
and residual activities were measured by the standard assay method. The buffers used were $0.1 \mathrm{M}$ hydrochloric acid-sodium acetate buffer $(\mathrm{pH} 1.0 \sim 4.5), 0.1 \mathrm{M}$ acetate buffer ( $\mathrm{pH} 4.0 \sim 6.5$ ), McIlvaine buffer ( $\mathrm{pH} 4.0 \sim 8.0$ ), $0.1 \mathrm{M}$ phosphate buffer ( $\mathrm{pH} 6.0 \sim 8.5$ ), $0.1 \mathrm{M}$ ammonia water-ammonium chloride buffer $(\mathrm{pH} 7.5 \sim 10.0)$ and 0.1 m glycine buffer (pH 9.5 12.5). Symbols: $\triangle-\triangle$, X-I; --- X-II-A; O---O, X-II-B.

\section{Effects of $p H$}

The enzyme activity was measured at various $\mathrm{pH}$ from 1.0 to 12.5 at $55^{\circ} \mathrm{C}$ with a $\mathrm{pH}$ meter (Horiba $\mathrm{pH}$ meter $\mathrm{M}-7$ ). The results were shown in Fig. 8. The optimal $\mathrm{pH}$ of X-I was $\mathrm{pH} 5.5 \sim 6.5$ and those of X-II-A and XII-B were both $\mathrm{pH} 5.0 \sim 6.0$. X-I had almost no 
activity under $\mathrm{pH} 3.0$ but X-II-A and X-II-B had $20 \sim 30 \%$ of their maximum activities at $\mathrm{pH} 2.0 \sim 3.0$. In the range of $\mathrm{pH} 9.0 \sim 11.0$ the activity of $\mathrm{X}$-I was about twice as much as those of X-II-A and X-II-B. For examinations of $\mathrm{pH}$ stability, the enzymes were incubated at

TABle II. EfFects of Various Chemicals ON THE ACTIVITY OF XYlanases

The enzyme activities were measured by the standard assay method. The activity is expressed as a percentage of the activity level in the absence of chemicals.

\begin{tabular}{lrrr}
\hline Reagents $\left(5 \times 10^{-3} \mathrm{M}\right)$ & $\mathrm{X}-\mathrm{I}$ & $\mathrm{X}$-II-A & $\mathrm{X}$-II-B \\
\hline None & 100 & 100 & 100 \\
$\mathrm{FeCl}_{3}$ & 26 & 25 & 25 \\
$\mathrm{HgCl}_{2}$ & 5 & 40 & 42 \\
$\mathrm{CuCl}_{2}$ & 64 & 65 & 69 \\
$\mathrm{BaCl}_{2}$ & 96 & 100 & 104 \\
$\mathrm{CaCl}_{2}$ & 92 & 90 & 88 \\
$\mathrm{MgCl}_{2}$ & 93 & 107 & 106 \\
$\mathrm{MnCl}_{2}$ & 85 & 85 & 84 \\
$\mathrm{NiCl}_{2}$ & 83 & 90 & 91 \\
$\mathrm{SnCl}_{2}$ & 75 & 75 & 74 \\
$\mathrm{ZnCl}$ & & 82 & 83 \\
$\mathrm{KCl}$ & 86 & 100 & 101 \\
$\mathrm{NaCl}_{\mathrm{LiCl}}$ & 96 & 101 & 103 \\
$\mathrm{KMnO}_{4}$ & 85 & 105 & 107 \\
$\mathrm{EDTA}$ & 106 & 81 & 82 \\
$\mathrm{SDS}$ & 85 & 77 & 76 \\
$\mathrm{NBS}$ & 98 & 40 & 43 \\
$\mathrm{PCMB}\left(1 \times 10^{-4} \mathrm{M}\right)$ & 24 & 10 & 10 \\
\hline & 51 & 70 & 69 \\
\hline
\end{tabular}

various $\mathrm{pH}$ for $30 \mathrm{~min}$ at $35^{\circ} \mathrm{C}$, and after that the remaining activities were assayed. X-I and two X-IIs were stable at $\mathrm{pH} 3.0 \sim 10.5$ and $1.5 \sim 11.5$, respectively (Fig. 9).

\section{Effects of chemicals}

The effects of metal ions, EDTA, SDS, $N$ bromosuccinimide, and $p$-chloromercuribenzoate on xylanases were shown in Table II. $\mathrm{Hg}^{2+}$ and $\mathrm{Fe}^{3+}$ ions, SDS and $\mathrm{N}$-bromosuccinimide inhibited the activities of all the three xylanases. X-I was greatly inhibited by $5 \mathrm{~mm} \mathrm{Hg}^{2+}$ ion or $N$-bromosuccinimide.

\section{Substrate specificity}

Substrates were incubated with the enzyme (6 units for xylan, xylotetraose, and xylotriose, or 100 units for xylobiose, cellobiose, maltose, soluble starch, and CM-cellulose) and Mcllvaine buffer ( $\mathrm{pH}$ 5.5) for $1 \mathrm{hr}$ at $40^{\circ} \mathrm{C}$. Increased reducing sugar was measured by Somogyi's method. Activities were expressed as $\mu \mathrm{g}$ of reducing sugar per unit of enzyme per minute. As shown in Table III, xylobiose, cellobiose, maltose, soluble starch, and CMcellulose were not attacked by the purified xylanase preparations. Xylan was hydrolyzed most easily and xylotetraose was done more easily than xylotriose.

The patterns of thin layer chromatography

Table III. Hydrolysis of Substrates by Xylanases

Substrate solutions $(1 \mathrm{ml})$ were incubated with $0.2 \mathrm{ml}$ of the xylanase $(6$ units for xylan, xylotetraose, and xylotriose, or 100 units for xylobiose, cellobiose, maltose, soluble starch, and CM-cellulose) and $0.8 \mathrm{ml}$ of McIlvaine buffer ( $\mathrm{pH} \mathrm{5.5)} \mathrm{for} 1 \mathrm{hr}$ at $40^{\circ} \mathrm{C}$. Activities were expressed as $\mu \mathrm{g}$ of reducing sugar per unit of enzyme per minute.

\begin{tabular}{|c|c|c|c|c|}
\hline \multirow{2}{*}{ Substrates } & \multirow{2}{*}{ Concentration } & \multicolumn{3}{|c|}{$\begin{array}{c}\text { Activity } \\
\left(\mu \mathrm{g} \text { of reducing sugar } \cdot \text { unit }^{-1} \min ^{-1}\right)\end{array}$} \\
\hline & & X-I & X-II-A & X-II-B \\
\hline Xylan & $1 \%$ & 37.5 & 37.5 & 37.5 \\
\hline Xylotetraose & $5 \mathrm{~mm}$ & 11.3 & 9.0 & 9.8 \\
\hline Xylotriose & $5 \mathrm{~mm}$ & 2.6 & 2.6 & 2.6 \\
\hline Xylobiose & $5 \mathrm{~mm}$ & & & \\
\hline Cellobiose & $5 \mathrm{~mm}$ & & & \\
\hline Maltose & $5 \mathrm{~mm}$ & n.d.* & n.d. & n.d. \\
\hline Soluble starch & $1 \%$ & & & \\
\hline CM-cellulose & $1 \%$ & & & \\
\hline
\end{tabular}

* n.d. $=$ not detected 


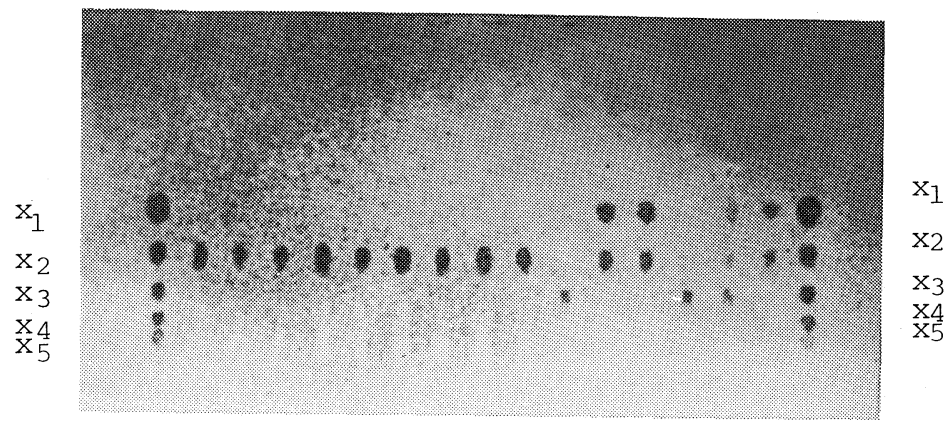

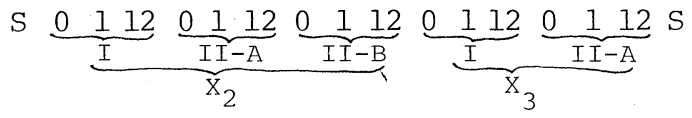

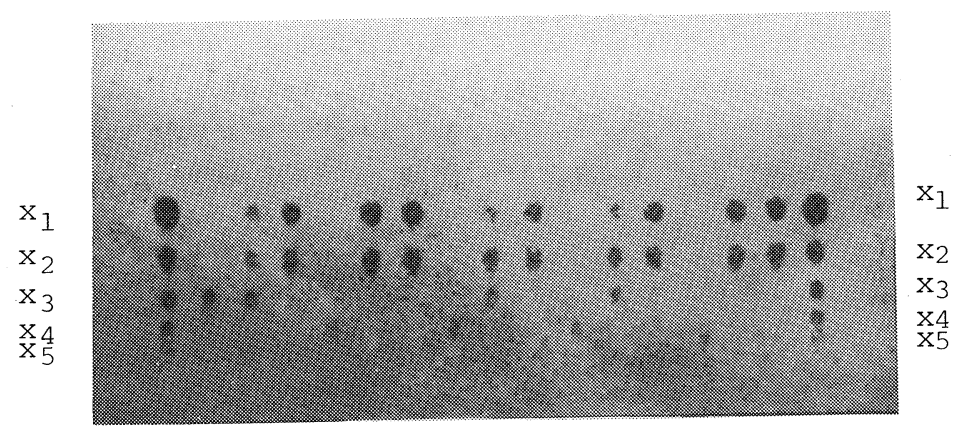

$S \underbrace{0 I 12}_{\substack{I I-B \\ X_{3}}} \underbrace{0 I 12}_{X_{4}} \underbrace{0 I 12}_{I I-A} \underbrace{0 I 12}_{I I-B} \underbrace{0 I 12}_{X_{5}} \mathrm{~S}$

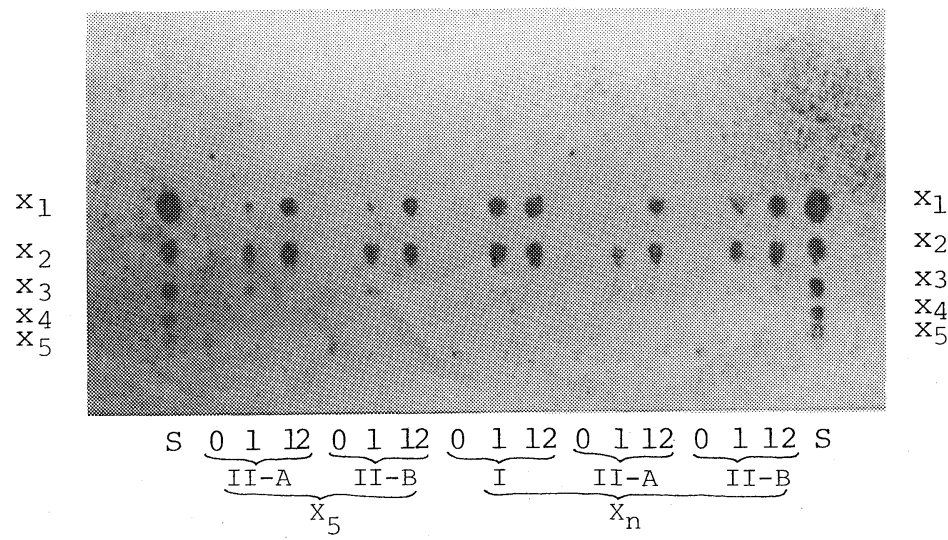

FIG. 10. Thin Layer Chromatography of Hydrolyzates of Xylooligosaccharides by Three Xylanases.

The reaction mixtures containing xylanase (10 units $/ \mathrm{ml}$ ) and $0.5 \%$ xylobiose, xylotriose, xylotetraose, xylopentaose, or xylan in McIlvaine buffer ( $\mathrm{pH} 5.5$ ) were incubated for $0 \sim 12 \mathrm{hr}$ at $35^{\circ} \mathrm{C}$. Samples of hydrolyzates were spotted on TLC plastic sheet cellulose, Merck. The solvent system was $n$ butanol-pyridine-water $(6: 4: 3$, by volume) at room temperature. Sugars were detected with silver nitrate-sodium hydroxide reagent. ${ }^{25)}$ Symbols: $\mathrm{X}_{1}$, xylose; $\mathrm{X}_{2}$, xylobiose; $\mathrm{X}_{3}$, xylotriose; $\mathrm{X}_{4}$, xylotetraose; $\mathrm{X}_{5}$, xylopentaose; $\mathrm{X}_{\mathrm{n}}$, xylan; I, xylanase X-I; II-A, xylanase X-II-A; II-B, xylanase X-II-B; S, standard $\left(\mathrm{X}_{1} \sim \mathrm{X}_{5}\right)$; 0 , incubațion time $0 \mathrm{hr} ; 1,1 \mathrm{hr} ; 12,12 \mathrm{hr}$. 
of xylooligosaccharide hydrolyzates are shown in Fig. 10. X-I, X-II-A, and X-II-B hydrolyzed xylotriose, xylotetraose, xylopentaose, and xylan to xylose and xylobiose, but were not able to attack xylobiose. At $1 \mathrm{hr}$ of incubation time, $\mathrm{X}-\mathrm{II}-\mathrm{A}$ and X-II-B showed xylotriose spots in the hydrolysis of xylotetraose, xylopentaose, and xylan. Both xylose and xylobiose were products by X-I, X-II-A, or X-II-B at $12 \mathrm{hr}$ of incubation time, except for xylobiose as a substrate.

\section{DISCUSSION}

A replacement culture method which consisted of a proliferating culture with glucose and an inducing culture with methyl $\beta$-xyloside increased the efficiency of xylanase production in Streptomyces sp. No. 3137. Since there was only a small amount of unnecessary proteins in the culture filtrate, after the 3 to 4 -fold purification of the culture filtrate, each purified enzyme, X-I, X-II-A, and X-II-B, showed a single protein band in polyacrylamide gel electrophoresis. For Streptomyces xylophagus, $\left.{ }^{3}\right)$ Streptomyces sp. ${ }^{24,25)}$ Aspergillus niger, ${ }^{26)}$ Schizophyllum commune, ${ }^{27)}$ Termitomyces clypeatus, ${ }^{28)}$ Bacillus sp. ${ }^{29)}$ Gliocladium virens, ${ }^{30)}$ and Talaromyces byssochlamydoides, ${ }^{31)}$ it needed 7 to 276-fold purifications of culture filtrate to get electrophoretically homogeneous preparations.

Enzyme systems of reported Streptomyces mostly were shown to consisted of one xylanase, ${ }^{3,24,25)}$ however, there was one report that the enzyme system of Streptomyces ostreogriseus consisted of many xylanases. ${ }^{7)}$ The xylanase from Streptomyces ostreogriseus was absorbed to DEAE-cellulose and a single peak of xylanase activity was obtained from Sephadex G-100 gel filtration. The five $x y-$ lanase fractions separated by gel electrophoresis were able to hydrolyze xylan to xylooligosaccharides, ${ }^{7)}$ however, no other properties were described in the report. ${ }^{7)}$

Three xylanases were induced by methyl $\beta$ xyloside from Streptomyces sp. No. 3137. The isoelectric point of X-I was much like those of known xylanases (pI 5.7 \pm 1.9 ), ${ }^{24,26,31 ~ 34)}$ and the isoelectric points of X-II-A and X-II-B were high values in comparison with those of X-I and the known xylanases. X-I, X-II-A, and $\mathrm{X}$-II-B had wider ranges of $\mathrm{pH}$ stability than those of known xylanases $(\mathrm{pH} 3.9 \pm 1.2 \sim$ $8.0 \pm 1.5) .^{3,24,26 \sim 32)}$

There was a strong similarity between X-II$A$ and X-II-B in chemical, physico-chemical, and enzymatic characters with a single exception of the isoelectric point. X-I was different from X-II-A and X-II-B in many respects, molecular weight, isoelectric point, and $\mathrm{pH}$ stability. X-I was twice as large as X-II-A or $\mathrm{X}-\mathrm{II}-\mathrm{B}$ in molecular weight, but it did not seem to be a dimer of X-IIs. The results of molecular weight estimation demonstrated that the xylanases from Streptomyces sp. No. 3137 are monomeric enzymes.

The three xylanases had the same ability to hydrolyze xylotriose, xylotetraose, and xylan (Table III). As shown in Fig. 9, they were able to convert xylotriose, xylotetraose, xylopentaose, and xylan to xylose and xylobiose, but not to hydrolyze xylobiose. They were like Streptomyces sp. E-86 xylanase, ${ }^{35)}$ and were partially different from Streptomyces sp. KT23 xylanase. $^{25}$ ) Transxylosidation reactions were not observed in the three xylanases as well as the E-86 and KT-23 enzymes.

Our studies show that X-II-A and X-II-B were very similar and X-I was obviously different from them in enzymatic properties and protein structure.

It is interesting to compare them with enzyme systems induced by xylan and by methyl $\beta$-xyloside, and this will be reported elsewhere.

Acknowledgment. We thank Dr. H. Inoue of National Institute of Agribiological Resources for the sedimentation analysis, and Sanyo Kokusaku Pulp Co., Ltd. and Nippon Shokuhinkako Co., Ltd. for supplying xylan and C.S.L., respectively.

\section{REFERENCES}

1) G. F. H. Dekker and G. N. Richard, Adv. Carbohydr. Chem., 32, 317 (1976).

2) I. Kusakabe, T. Yasui and T. Kobayashi, Nippon 
Nôgeikagaku Kaishi, 43, 145 (1969).

3) H. Iizuka and T. Kawaminami, Agric. Biol. Chem., 29, 520 (1965).

4) H. Iizuka and T. Kawaminami, Agric. Biol. Chem., 33, 1257 (1969).

5) T. Kawaminami and H. Iizuka, Agric. Biol.. Chem., 33, 1787 (1969).

6) H. R. Goldschmid and A. S. Perlin, Can. J. Chem., 41, 2272 (1963).

7) Y. K. Park and M. Toma, Korean. J. Biochem., 14, 37 (1982).

8) K. Nakanishi, T. Yasui and T. Kobayashi, $J$. Ferment. Technol., 54, 813 (1976).

9) K. Nakanishi, T. Yasui and T. Kobayashi, $J$. Ferment. Technol., 54, 801 (1976).

10) T. Yasui, K. Nakanishi and T. Kobayashi, Hakkokogaku, 58, 79 (1980).

11) K. Nakanishi and T. Yasui, Agric. Biol. Chem,, 44, 1885 (1980).

12) K. Nakanishi, Doctoral thesis (1980).

13) Society for the study of microbiology, "Experimental Methods in Microbiology," Kodansha, 1975, p. 423.

14) I. Kusakabe, T. Yasui and T. Kobayashi, Agric. Biol. Chem., 39, 1355 (1975).

15) I. Kusakabe, T. Yasui and T. Kobayashi, Nippon Nôgeikagaku Kaishi, 49, 383 (1975).

16) G. N. Bollenback, "Methods in Carbohydrate Chemistry," Vol. II, ed. by R. L. Whistler and M. L. Wolfrom, Academic Press Inc., New York, 1962, p. 326.

17) M. Somogyi, J. Biol. Chem., 169, 61 (1945).

18) O. H. Lowry, N. J. Rosebrough, A. L. Farr and R. J. Randall, J. Biol. Chem., 193, 265 (1951).

19) M. Dubois, K. A. Gilles, J. K. Hamilton, P. A. Rebers and F. Smith, Analyt. Chem., 28, 350 (1956).
20) W. R. Fernell and H. K. King, Analyst, 78, 80 (1953).

21) K. A. Reisfeld, U. J. Lewis and D. E. Willians, Nature, 195, 281 (1962).

22) O. Vesterberg, "Methods in Enzymology," Vol. XXII, ed. by W. B. Jakoby, Academic Press Inc., New York, 1971, p. 389.

23) W. E. Trevelyan, D. P. Procter and J. S. Harrison, Nature, 166, 444 (1950).

24) I. Kusakabe, M. Kawaguchi, T. Yasui and T. Kobayashi, Nippon Nôgeikagaku Kaishi, 51, 429 (1977).

25) T. Nakajima, K. Tsukamoto, T. Watanabe, K. Kainuma and K. Matsuda, J. Ferment. Technol., 62 , 269 (1984).

26) I. V. Gorbacheva and N. A. Rodionova, Biochim. Biophys. Acta, 484, 79 (1977).

27) M. G. Praice, L. Jurasek, M. R. Carpenter and L. B. Smillie, Appl. Environ. Microbiol., 36, 802 (1978).

28) A. K. Ghosh, P. C. Banerjee and S. Sengupta, Biochim. Biophys. Acta, 612, 143 (1980).

29) F. Uchino and T. Nakane, Agric. Biol. Chem., 45, 1121 (1981).

30) M. Takahashi and S. Kutsumi, J. Ferment. Technol., 57, 434 (1979).

31) H. Yoshioka, N. Nagato, S. Chavanich, N. Nilubol and S. Hayashida, Agric. Biol. Chem., 45, 2425 (1981).

32) M. M. Frederick, J. R. Frederick, A. R. Fratzke and P. J. Reilly, Carbohydr. Res., 97, 87 (1981).

33) R. Esteban, J. R. Villanueva and T. G. Villa, Can. J. Microbiol., 28, 733 (1982).

34) M. Vrsanska, I. V. Gorbacheva, Z. Kratky and P. Biely, Biochim. Biophys. Acta, 704, 114 (1982).

35) I. Kusakabe, T. Yasui and T. Kobayashi, Nippon Nôgeikagaku Kaishi, 51, 439 (1977). 